\title{
Study of the sorption capacity of soluble forms of yeast beta-glucan
}

\author{
(C) Anna S. Kurochkina, and Alla A. Krasnoshtanova*+ \\ Department of Biotechnology. D. Mendeleev University of Chemical Technology of Russia. Miusskaya Sq, 9. \\ Moscow, 125047. Russia.Phone: +7 (495) 495-2379.E-mail: aak28@yandex.ru
}

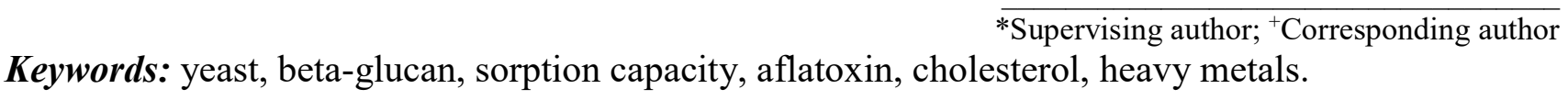

\begin{abstract}
Beta-glucans are polysaccharides that consist of $D$-glucose residues linked together in the main and side chains by glycosidic bonds. They are obtained from plant and microbial raw materials. Beta-glucans obtained from various sources differ in molecular weight, backbone length, branching of additional chains and their number. Beta-(1,3,1,6)-glucan from the yeast Saccharomyces cerevisiae has the highest physiological activity. The soluble fraction of beta-glucan has a higher physiological activity than its insoluble fraction.

As a rule, soluble beta-glucans appear to be more potent immunostimulants than insoluble ones. In this regard, obtaining soluble forms of beta-glucan from yeast is relevant.

The purpose of this work was to study the effect of the content of the soluble fraction in yeast betaglucan on the ability to adsorb heavy metal ions, mycotoxins and cholesterol.

Evaluation of the effectiveness of ultrasonic treatment for obtaining soluble forms of yeast beta-glucan was carried out. It was found that the maximum content of the soluble fraction, equal to $95 \%$, at a frequency of ultrasonic treatment of $85 \mathrm{kHz}$ for a laboratory sample of beta-glucan, is achieved with a treatment time of $20 \mathrm{~min}$, and for a commercial one - in $30 \mathrm{~min}$. The sorption properties of soluble forms of yeast beta-glucan with different content of the soluble fraction in relation to cholesterol, aflatoxin and bivalent copper cations were studied. The sorption capacity of samples of laboratory and commercial preparations of beta-glucan was determined for the above compounds. It was found that an increase in the content of the soluble fraction to more than $50 \%$ does not lead to a noticeable increase in the sorption capacity. It was shown that purified samples of beta-glucan have higher sorption characteristics.
\end{abstract}

\section{References}

[1] C. Barton [et al.]. Beta-glucan contamination of pharmaceutical products: How much should we accept? Cancer Immunology, Immunotherapy. 2016. Vol.65. No.11. P.1289-1301.

[2] J. Lehmann, R. Kunze. Water-soluble low molecular weight beta-glucans for modulating responses in mammalian system. Pat. USA. № 6143883. pub. 07.11.2000.

[3] V. Vetvicka. Effects of $\beta$-glucan on some environmental toxins: An overview. Biomedical Papers. 2014. Vol.158. No.1. P.1-4.

[4] A. Huwig, S. Freimund, O. Kappeli, and H. Dutler. Mycotoxin detoxication of animal feed by different adsorbents. Toxicology Letters. 2001. Vol.122. P.179-188.

[5] Z.A. Kanarskaya. Influence of yeast cell wall polysaccharides on the efficiency of T-2 mycotoxin adsorption. Bulletin of Kazan Technological University. 2012. No.16. P.162-168. (russian)

[6] A. Bzducha-Wrobel, S. Blazejak. Antitoxic and antimicrobial properties of the yeast cell wall components. Medycyna Weterynaryjna. 2011. Vol.67. No.4. P.244-249.

[7] A. Bzducha-Wrobel, M. Bryla, I. Gientka, S. Blazejak, M. Janowicz. Candida utilis atcc 9950 cell walls and $\beta(1,3) /(1,6)$-glucan preparations produced using agro-waste as a mycotoxins trap. Toxins. 2019. Vol.11. No.4. P.192.

[8] A. Khanafari, H. Soudi, and M. Miraboulfathi. Biocontrol of Aspergillus flavus and aflatoxin B1 production in corn. Journal of Environmental Health Science and Engineering. 2007. Vol.4. P.163-168.

[9] C.M. Pereyra [et al.]. The corn influence on the adsorption levels of aflatoxin B1 and zearalenone by yeast cell wall. Journal of applied microbiology. 2013. Vol.114. No.3. P.655-662.

[10] A. Yiannikouris, G. Andre, L. Poughon, G. Bertin, J.-P. Jouany. Chemical and conformational study of the interactions involved in mycotoxin complexation with $\beta$-D-glucans. Biomacromolecules. 2006.

Vol.7. No.4. P.1147-1155. 
[11] A. Yiannikouris, J. Francois, L. Poughon, G. Jeminet, J.-P. Jouany. Alkali extraction of $\beta$-D-glucans from Saccharomyces cerevisiae cell wall and study of their adsorptive properties toward zearalenone. Journal of Agricultural and Food Chemistry. 2004. Vol.52. No.11. P.3666-3673

[12] S.D. Aronbaev, A.M. Nasimov, D.M. Aronbaev. Biosorption of heavy metals by cell membranes of the yeast Saccharomyces cerevisiae. All-Russian journal of scientific publications. 2011. No.1(2). P.13-15. (russian)

[13] T.V. Smotrina, and L.A. Kiseleva. Structural changes of mushroom chitin-glucan complexes caused by Cuprum (II) ions sorption. Butlerov Communications. 2013. Vol.34. No.4. P.135-139. ROI-jbc-02/1334-4-135

[14] A.S. Salomatov, A.D. Toshev, V.A. Vaskina, G.N. Goryacheva. A new type of raw material from pearl barley for use in confectionery technology. Bulletin of the South Ural State University. Series: Food and Biotechnology. 2015. Vol.3. No.1. P.24-32. (russian)

[15] S. Naumann, U. Schweiggert-Weisz, S. Bader-Mittermaier, D. Haller, P. Eisner. Differentiation of adsorptive and viscous effects of dietary fibres on bile acid release by means of in vitro digestion and dialysis. International Journal of Molecular Sciences. 2018. Vol.19. No.8. P.2193.

[16] J. Lehmann [et al.]. Water-soluble low molecular weight beta-glucans for modulating immunological responses in mammalian system. Pat. USA № 6143883. pub. 07.11.2000.

[17] G.A. Manukyan, and A.A. Krasnoshtanova. Selection of conditions of preliminary treatment of yeast for obtaining $\beta$-glucan. Butlerov Communications. 2017. Vol.50. No.5. P.88-94. DOI: 10.37952/ROIjbc-01/17-50-5-88

[18] C. Brera, F. Debegnach, V. Minardi [et al.]. Immunoaffinity Column Cleanup with Liquid Chromatography for Determination of Aflftoxin B 1 in Corn Samples: Interlaboratory Study. J. AOAC Int. 2007. Vol.90. No.3. P.765.

[19] A.A. Krasnoshtanova, V.I. Panfilov. Dissolution of copper from ore using amino acids and yeast protein hydrolyzate. Non-ferrous metals. Tsvetnye Metally. 2019. No.10. P.12-17. (russian) 